\title{
Effect of Some Plant Powders against Fusarium spp. and Macrophomina phaseolina Under Greenhouse Conditions
}

\author{
F. A. Abushaala ${ }^{1}$ A. R. Ben Ramadanm ${ }^{1}$, M. A. S. Fahej ${ }^{2}$ \\ ${ }^{1}$ Microbiology Department, Faculty of Science, Misurata University, Libya \\ ${ }^{2}$ Biology Department, Faculty of Science, Elmergib University, Al-khoms, Libya
}

\begin{abstract}
Chemical fungicides cause serious environmental problems. Plant based pesticides considered to be better alternatives as they are known to have minimal environmental impact in contrast to synthetic pesticides. The aim of this study was to assess the efficiency of some plant powders on controlling damping-off disease incited by the tested pathogens under greenhouse conditions. Seed treatment with the tested plant powders significantly reduced TIP values incited by the tested seed-born pathogens. The highest reduction rate (37.5\%) was detected in $R$. raetam / F. semitictum / CREDO cv. treatment, whereas the least rate (4.55\%) was realized in C. trifurcatum F. semitictum and F. moniliforme interactions in ANANAS cv.. The highest TIP reduction rates (33.33\%, 23.53\% and $22.22 \%$ ) were observed in $R$. raetam / F. solani, $R$. raetam / F. moniliforme and $R$. raetam / M. phaseolina treatments, respectevily. The highest reduction rate (25.0\%) was detected in $P$. dactylifera / F. semitictum and F. solani interactions in CREDO cv. Significant reduction in PRD values was detected as a result of seed treatment with the tested plant extract, attaining maximum rates in $R$. raetam $/$ F. solani (43.75\%), F. semitictum (33.33\%), M. phaseolina (28.57\%) and F. moniliforme (23.07\%), while in P. dactylifera treatment gave the highest reduction rates $(37.5 \%, 26.32 \%$ and $25.0 \%)$ were observed in F. solani / CREDO cv., F. solani / ANANAS cv. and M. phaseolina / ANANAS cv. Significant reductions PTD in damping-off incidence in all cantaloupe cultivars were obtained due to treatment with most of the tested plant powders, but in some treatments were non effected, however, $R$. raetam was more efficient in reducing damping-off incited by $F$. semitictum, $F$. moniliforme and $F$. solani $(42.86 \%, 28.57 \%$ and $27.27 \%$, respectively compared with control). On the other hand, $P$. dactylifera and $C$. trifurcatum were more efficient in controlling damping-off caused by $F$. semitictum, where reduction\%, compared damping-off incidence. Generally, $R$. raetam was more effected to controlling the tested pathogenic fungi followed by P. dactylifera.
\end{abstract}

Keywords: Damping-off pathogens, Plant powders, cucurbit seed-borne fungi, Antifungal activity

\section{Introduction}

Fungicides like many other chemicals that used for pathogens control have negative environmental consequensis. So, the modern approach in plant disease control is directed toward minimizing the fungicidal use to decrease environmental pollution and finding alternatives to chemical fungicides. Hence, in recent time application of plant powders as well as plant metabolites for plant disease management has become important viable component of integrated Pest Management, as these plant products are ecofriendly where botanicals place an important role (Sahayaraj et al., 2009). Several investigation studies have been conducted in order to screening different plants for their antifungal properties (Ja Choi et al., 2004; Stephan et al., 2005; Satish et al., 2010) and biochemical compounds that these plants have. Studies revealed a highly significant antifungal activity of some water extracts or essential oils of plants. Since some plants are already known to possess several biological activities (Amin et al., 2009; Barrera-Necha et al., 2009; Belabid et al., 2010). Therefore, the objective of this work was to controlling the isolated damping-off pathogens, using some plant powders under greenhouse conditions.

\section{Materials and Methods}

\subsection{Disease Control}

\subsubsection{In vivo experiments}

Soil was autoclaved at $1.5 \mathrm{Kg} / \mathrm{cm} 2$ for 90 minutes and then left to aerate for 7 days before adding the inoculum. Inocula were prepared by growing each of the tested pathogens $(F$. solani, F. moniliforme, F. semitectum and M. phaseolina) on PD medium in $250 \mathrm{ml}$ conical flasks, each containing $50 \mathrm{ml}$ of medium and incubated at $25^{\circ} \mathrm{C}$ for 15 days. After 15 days incubation, fungal mats were collected, blended with sterile water. The inocula were used at rate of $3 \mathrm{~g} / \mathrm{Kg}$ autoclaved soil.

Seeds of cantaloupe cultivars (CREDO F1, ISI $54139 \mathrm{~F} 1$ and ANANAS) were soaked in a 5\% sugar solution for 30 seconds after surface disinfestations with $3 \%$ sodium hypochlorite. Pots $(12 \mathrm{~cm}$ in diameter) were sterilized by immersing them in $5 \%$ formalin solution for 15 minutes, then left for several days to get rid of the poisonous effect of formalin. Autoclaved soil mixture $(50 \%$ sand and 50\% loam) was applied. The soil infested with the tested fungi was left for one week for pathogen establishment. The sticky seeds were fully mixed with the dried powder of the extracts, namely: Retama raetam (mixed of flowers, Stems and fruits) and Phoenix dactylifera (seeds) were collected from Misurata region in north Libya, while Chrysanthemum trifurcatum (mixed of leaves, stems and roots) in the target treatment. The proportion of the extract was about $10 \%$ of 


\section{International Journal of Science and Research (IJSR) \\ ISSN (Online): 2319-7064}

Index Copernicus Value (2015): 78.96 | Impact Factor (2015): 6.391

the weight of the seeds. Seed dressing was carried out by mixing the seeds thoroughly with the tested plant extracts before sowing. Pots filled with sterile sandy clay soil were inoculated with each of the tested fungi and sown with treated seeds as mentioned in the pathogenicity test (10 seeds/pot). Four replicates (4 pots) of each treatment were used. Similar treatments with untreated seeds were used as a control. Data were recorded 14 days after germination. Percentages of seedling infection were recorded as a reflection for pre- and post-emergence damping-off percentages (Bahraminejad, 2012).

\section{Experimental Results}

This study was carried out to evaluate efficacy of some plant powders in controlling diseases caused by the tested seedborne pathogens in vivo. Seed treatment by different plant powders $(10 \% \mathrm{w} / \mathrm{w})$, i.e. $R$. raetam (flowers, fruits and Stems), $C$. trifurcatum (all of plant) and $P$. dactylifera (seeds), on the incidence of PRD, PTD and TIP, incited by four of the isolated cucurbitaceous seed-borne pathogens, i.e. F. solani, F. moniliforme, F. semitectum, M. phaseolina. PRD, PTD and consequently TIP values were then measured and presented in Tables (1-4)

1. F. solani (Table 1): Results of Table (1) indicate that:

1) Significant reductions in PRD values were observed in cantaloupe cvs. as a result of seed treatment with any of the tested plant powders. On the other hand, all tested cantaloupe cvs. showed significant reductions in PRD incidence incited by $F$. solani, as a result of seed treatment with any of the tested plant powders, compared with control. $R$. raetam proved to the most effective in reducing infection by $F$. solani in all cantaloupe cvs., compared with the other plant powders. Reductions in PRD \% with $R$. raetam were, $43.75 \%, 29.41 \%$ and
$31.58 \%$, followed by $P$. dactylifera $37.5 \%, 23.53 \%$ and $26.32 \%$ in CREDO F1, ISI $54139 \mathrm{~F} 1$ and ANANAS, respectively. Lower reduction rates were obtained with C. trifurcatum (31.25\%, $17.65 \%$ and $21.05 \%$, respectively.

2) Results of PTD occurrence after seed treatment with different plant powders revealed that, $C$. trifurcatum and $P$. dactylifera were ineffective and resulted in insignificant reductions in PTD, incited by $F$. solani, in both CREDO F1cv. and ANANAS cv. The other plant powders treatments significantly reduced PTD incidence, however, $R$. raetam treatment realized the highest reductions all in cantaloupe cvs. $(12.50 \%, 27.27 \%$ and 9.10\%, respectively). C. trifurcatum and P. dactylifera, since it reduced PTD values, in the previously ISI 54139 F1 $9.10 \%$ and $18.18 \%$, respectively, compared with control.

3) In general, cantaloupe seed treatment with the tested different plant powders significantly reduced TIP values incited by $F$. solani, however, suppression rates differed according to the tested different plant powders and cultivar. Generally, $R$. raetam was the most efficient plant powders in reducing TIP in all cantaloupe cvs. since reduction rates ranged from $23.33 \%$ to $33.33 \%$, compared with control. In CREDO F1 cv., $R$. raetam was the most suppressive against damping-off disease than the other tested plant powders, attaining reduction rate $33.33 \%$. $P$. dactylifera came next to $R$. raetam, since it realized less reduction rates $(25 \%, 21.43$ and $16.67 \%$ in CREDO F1, ISI $54139 \mathrm{~F} 1$ and ANANAS cvs., respectively, compared with control). Treatment of cantaloupe seeds with $C$. trifurcatum resulted in the least efficiency rates, since reductions in TIP \% were (20.83\%, $14.28 \%$ and $13.33 \%$ in CREDO F1, ISI 54139 F1 and ANANAS cvs., respectively, compared with control).

Table 1: Efficiency of Seed coating with some Plant powders agents on controlling damping-off of cantaloupe cvs., incited by $F$. solani.

\begin{tabular}{|c|c|c|c|c|c|c|c|c|c|c|}
\hline \multirow{4}{*}{ Treatment } & \multicolumn{9}{|c|}{ Percentage of seedling infection ( PSI ) } & \multirow{4}{*}{$\begin{array}{c}\text { Mean } \\
\text { values } \\
\text { TIP }\end{array}$} \\
\hline & \multicolumn{9}{|c|}{ Varieties } & \\
\hline & \multicolumn{3}{|c|}{ CREDO F1 } & \multicolumn{3}{|c|}{ ISI 54139 F1 } & \multicolumn{3}{|c|}{ ANANAS } & \\
\hline & PRD & PTD & TIP & PRD & PTD & TIP & PRD & PTD & TIP & \\
\hline F. solani $+R$. reatam & 22.5 & 17.5 & 40 & 30 & 20 & 50 & 32.5 & 25 & 57.5 & 49.17 \\
\hline F. solani + C. trifurcatum & 27.5 & 20 & 47.5 & 35 & 25 & 60 & 37.5 & 27.5 & 65 & 57.50 \\
\hline$F$. solani $+P$. dactylifera & 25 & 20 & 45 & 32.5 & 22.5 & 55 & 35 & 27.5 & 62.5 & 54.17 \\
\hline Control (1)(F. solani alone) & 40 & 20 & 60 & 42.5 & 27.5 & 70 & 47.5 & 27.5 & 75 & 68.33 \\
\hline Control (2) (Untreated) & 0.0 & 0.0 & 0.0 & 2.5 & 0.0 & 2.5 & 2.5 & 0.0 & 2.5 & 1.67 \\
\hline L.S.D & 1.88 & 1.57 & 2.24 & 1.78 & 1.49 & 2.66 & 1.92 & 1.39 & 2.98 & \\
\hline
\end{tabular}

PRD = Pre emergence damping-off, PTD = Post emergence damping-off, TIP = Total infection percentage,

PSI $=$ Percentage of seedling infection .

Table 2: Efficiency of Seed coating with some Plant powders agents on controlling damping-off of cantaloupe cvs., incited by $F$. moniliforme.

\begin{tabular}{|c|c|c|c|c|c|c|c|c|c|c|}
\hline \multirow{4}{*}{ Treatment } & \multicolumn{9}{|c|}{ Percentage of seedling infection ( PSI ) } & \multirow{4}{*}{$\begin{array}{l}\text { Mean } \\
\text { values } \\
\text { TIP }\end{array}$} \\
\hline & \multicolumn{9}{|c|}{ Varieties } & \\
\hline & \multicolumn{3}{|c|}{ CREDO F1 } & \multicolumn{3}{|c|}{ ISI $54139 \mathrm{~F} 1$} & \multicolumn{3}{|c|}{ ANANAS } & \\
\hline & PRD & PTD & TIP & PRD & PTD & TIP & PRD & PTD & TIP & \\
\hline$F$. moniliforme $+R$. reatam & 20 & 12.5 & 32.5 & 25 & 15 & 40 & 30 & 17.5 & 47.5 & 40.00 \\
\hline $\begin{array}{c}F . \text { moniliforme }+C . \\
\text { trifurcatum }\end{array}$ & 22.5 & 15 & 37.5 & 27.5 & 17.5 & 45 & 32.5 & 20 & 52.5 & 45.00 \\
\hline $\begin{array}{l}\text { F. moniliforme }+P . \\
\text { dactylifera }\end{array}$ & 20 & 15 & 35 & 25 & 17.5 & 42.5 & 30 & 20 & 50 & 42.50 \\
\hline Control (1) ( $F$. moniliforme & 25 & 17.5 & 42.5 & 32.5 & 17.5 & 50 & 35 & 20 & 55 & 49.17 \\
\hline
\end{tabular}

Volume 6 Issue 7, July 2017 www.ijsr.net 
International Journal of Science and Research (IJSR)

ISSN (Online): 2319-7064

Index Copernicus Value (2015): 78.96 | Impact Factor (2015): 6.391

\begin{tabular}{|c|c|c|c|c|c|c|c|c|c|c|}
\hline alone) & & & & & & & & & & \\
\hline Control (2) (Untreated) & 0.0 & 0.0 & 0.0 & 0.0 & 0.0 & 0.0 & 2.5 & 0.0 & 2.5 & 0.83 \\
\hline L.S.D & 1.54 & 1.27 & 2.11 & 1.87 & 1.38 & 1.79 & 1.61 & 1.23 & 1.92 & \\
\hline
\end{tabular}

PRD = Pre emergence damping-off, PTD = Post emergence damping-off, TIP = Total infection percentage,

PSI $=$ Percentage of seedling infection .

Table 3: Efficiency of Seed coating with some Plant powders agents on controlling damping-off of cantaloupe cvs., incited by $F$. semitectum.

\begin{tabular}{|c|c|c|c|c|c|c|c|c|c|c|}
\hline \multirow{4}{*}{ Treatment } & \multicolumn{9}{|c|}{ Percentage of seedling infection ( PSI ) } & \multirow{4}{*}{$\begin{array}{c}\text { Mean } \\
\text { values } \\
\text { TIP }\end{array}$} \\
\hline & \multicolumn{9}{|c|}{ Varieties } & \\
\hline & \multicolumn{3}{|c|}{ CREDO F1 } & \multicolumn{3}{|c|}{ ISI 54139 F1 } & \multicolumn{3}{|c|}{ ANANAS } & \\
\hline & PRD & PTD & TIP & PRD & PTD & TIP & PRD & PTD & TIP & \\
\hline F. semitectum + R. reatam & 15 & 10 & 25 & 22.5 & 15 & 37.5 & 30 & 17.5 & 47.5 & 36.67 \\
\hline $\begin{array}{c}F . \text { semitectum }+C . \\
\text { trifurcatum }\end{array}$ & 22.5 & 12.5 & 35 & 27.5 & 17.5 & 45 & 32.5 & 20 & 52.5 & 44.17 \\
\hline $\begin{array}{c}F . \text { semitectum }+P . \\
\text { dactylifera }\end{array}$ & 17.5 & 12.5 & 30 & 25 & 15 & 40 & 30 & 20 & 50 & 40.00 \\
\hline $\begin{array}{c}\text { Control (1) } \\
\text { (F. semitectum alone) }\end{array}$ & 22.5 & 17.5 & 40 & 27.5 & 20 & 47.5 & 35 & 20 & 55 & 47.50 \\
\hline $\begin{array}{l}\text { Control (2) } \\
\text { (Untreated) }\end{array}$ & 0.0 & 0.0 & 0.0 & 0.0 & 0.0 & 0.0 & 0.0 & 0.0 & 0.0 & 0.00 \\
\hline L.S.D & 1.44 & 1.69 & 2.63 & 1.63 & 1.40 & 2.05 & 1.88 & 1.71 & 2.27 & \\
\hline
\end{tabular}

PRD = Pre emergence damping-off, PTD = Post emergence damping-off, TIP = Total infection percentage,

PSI $=$ Percentage of seedling infection .

Table 4: Efficiency of Seed coating with some Plant powders agents on controlling damping-off of cantaloupe cvs., incited by $M$. phaseolina

\begin{tabular}{|c|c|c|c|c|c|c|c|c|c|c|}
\hline \multirow{4}{*}{ Treatment } & \multicolumn{9}{|c|}{ Percentage of seedling infection ( PSI ) } & \multirow{4}{*}{$\begin{array}{l}\text { Mean } \\
\text { values } \\
\text { TIP }\end{array}$} \\
\hline & \multicolumn{9}{|c|}{ Varieties } & \\
\hline & \multicolumn{3}{|c|}{ CREDO F1 } & \multicolumn{3}{|c|}{ ISI $54139 \mathrm{~F} 1$} & \multicolumn{3}{|c|}{ ANANAS } & \\
\hline & PRD & PTD & TIP & PRD & PTD & TIP & PRD & PTD & TIP & \\
\hline M. phaseolina + R. reatam & 20 & 15 & 35 & 25 & 20 & 45 & 32.5 & 22.5 & 55 & 45.00 \\
\hline $\begin{array}{c}\text { M. phaseolina }+C . \\
\text { trifurcatum }\end{array}$ & 22.5 & 20 & 42.5 & 32.5 & 20 & 52.5 & 35 & 25 & 60 & 51.67 \\
\hline $\begin{array}{l}\text { M. phaseolina }+P . \\
\text { dactylifera }\end{array}$ & 22.5 & 17.5 & 40 & 30 & 20 & 50 & 30 & 25 & 55 & 48.33 \\
\hline $\begin{array}{c}\text { Control (1) } \\
\text { (M. phaseolina alone) }\end{array}$ & 25 & 20 & 45 & 35 & 22.5 & 57.5 & 40 & 25 & 65 & 55.83 \\
\hline $\begin{array}{l}\text { Control (2) } \\
\text { (Untreated) }\end{array}$ & 0.0 & 0.0 & 0.0 & 0.0 & 0.0 & 0.0 & 2.5 & 2.5 & 5 & 1.67 \\
\hline L.S.D & 1.13 & 1.54 & 1.77 & 1.31 & 1.67 & 1.86 & 1.22 & 1.48 & 2.12 & \\
\hline
\end{tabular}

$\mathrm{PRD}=$ Pre emergence damping-off, PTD = Post emergence damping-off, TIP = Total infection percentage,

PSI $=$ Percentage of seedling infection.

2. F. moniliforme (Table 2): According to data shown in Table (2), the following could be concluded:

1) All seed treatments with the tested different plant powders were significant in decreasing PRD incidence, however, $R$. raetam and $P$. dactylifera were the most effective among them, since reduction rates were equal values $(20 \%, 23.07 \%$ and $14.28 \%$, respectively, CREDO F1, ISI $54139 \mathrm{~F} 1$ and ANANAS cvs.. The least effiency rates among the tested plant extracts was that of $C$. trifurcatum in all cantaloupe cultivars.

2) Seed treatments with the C. trifurcatum or P. dactylifera, all the obtained PTD values, were insignificant, compared with control, except in CREDO F1 cv. However, pronounced and significant PTD values were recorded throughout the experiment in all $R$. raetam cantaloupe treatments, however, the best controlling results were detected in $R$. raetam treatments $(12.5 \%$ to $28.57 \%$ less than control).

3) TIP values were significantly reduced as a result of seed treatment with the tested different plant powders in all cantaloupe cultivars. However, the highest disease suppression rates were detected in $R$. raetam treatments (23.53\%, 20\% and $13.65 \%$ in CREDO F1, ISI $54139 \mathrm{~F} 1$ and ANANAS cvs., compared with control, respectively). C. trifurcatum and $P$. dactylifera were also efficient but at rates lower than those of $R$. raetam. The least effective plant extract was $C$. trifurcatum. This was true for all tested cultivars.

3. F. semitectum (Table 3): Results presented in Table 3 show that:

1) All plant powders /cultivar treatments significantly suppressed PRD, incited by $F$. semitectum except two treatments e.i. CREDO F1or ISI 54139 F1 with $C$. trifurcatum. However, $P$. dactylifera significant with relatively lower effiency in disease suppression. The highest reduction in PRD values were observed in all $R$. raetam treatments, including CREDO F1, ISI 54139 F1 and ANANAS cvs. $(33.33 \%, 18.18 \%$ and $14.24 \%$, compared with control, respectively).

2) Values of PTD as affected by seed treatment with the tested different plant powders showed a great diversity

\section{Volume 6 Issue 7, July 2017 www.ijsr.net}

Licensed Under Creative Commons Attribution CC BY 


\section{International Journal of Science and Research (IJSR) \\ ISSN (Online): 2319-7064}

Index Copernicus Value (2015): 78.96 | Impact Factor (2015): 6.391

among the tested cultivars. In cantaloupe, the highest PTD reduction rates were realized by $R$. raetam (42.86 in CREDO F1), followed by $C$. trifurcatum or P. dactylifera with CREDO F1 cv. (28.57\%). C. trifurcatum or P. dactylifera treatments with ANANAS cv. were insignificant.

3) Generally, results showed that, TIP of $F$. semitectum were greatly and significantly reduced as a result of seed treatments with all the tested plant powders. However, the highest reduction values in TIP were recognized in $R$. raetam in all cantaloupe cvs. (37.5\%, 21.05 and $13.65 \%$ in CREDO F1, ISI $54139 \mathrm{~F} 1$ and ANANAS cvs, respectively). The lowest reduction rates were realized by $C$. trifurcatum, which ranged $4.55 \%$ to $12.5 \%$.

4. M. phaseolina (Table 4):Data in Table (4) reveal that:

1) All the tested plant powders treatments successfully reduced PRD incidence incited by $M$. phaseolina, however, $R$. raetam showed the highest PRD decreasing rates in ISI $54139 \mathrm{~F} 1$ cultivar $(28.57 \%)$ and in both CREDO F1 and ANANAS cultivars $(20.00 \%$ and $18.75 \%$, respectively). C. trifurcatum was as effective as $P$. dactylifera / CREDO F1 cv. treatment. The least effective treatment was detected in $C$. trifurcatum treatment with ISI $54139 \mathrm{~F} 1 \mathrm{cv} .(7.14 \%)$. P. dactylifera / ANANAS cv. came next to $R$. raetam, (25\%).

2) PTD values showed different trends in cantaloupe cultivars. In ANANAS cultivar, the only significant reduction was realized by $R$. raetam $(10.00 \%)$, however, all the other plant extract / ISI 54139 F1 were significant, compared with control, whereas in CREDO F1 cultivar, the highest significant reduction were obtained in $R$. raetam (25\%), since it highly suppressed disease incidence, followed by $P$. dactylifera, insignificant PTD value was produced $R$. raetam / CREDOF1cv.treatment.

3) Total infection percentages (TIP) expressed the highest reductions, compared with control, in $R$. raetam in all cultivars treatments $(22.22 \%, 21.74 \%$ and $15.38 \%$ in CREDO F1, ISI $54139 \mathrm{~F} 1$ and ANANAS cvs, respectively). $P$. dactylifera treatments were also effective but still less efficient than $R$. raetam, since it reduced TIP incidence in CREDO F1, ISI $54139 \mathrm{~F} 1$ and ANANAS cvs, at $11.11 \%, 13.04 \%$ and $15.38 \%$, respectively. C. trifurcatum was the least effective in all tested treatments, compared with control.

\section{Discussion}

Seed treatment with the tested plant powder significantly reduced TIP values incited by the tested seed-born pathogens. The highest reduction rate $(37.5 \%)$ was detected in $R$. raetam / $F$. semitictum / CREDO cv. Treatment, whereas the least rate $(4.55 \%)$ was realized in C. trifurcatum $F$. semitictum and $F$. moniliforme interactions in ANANAS cv.. The highest TIP reduction rates $(33.33 \%, 23.53 \%$ and $22.22 \%$ ) were observed in $R$. raetam / F. solani, $R$. raetam / $F$. moniliforme and $R$. raetam / $M$. phaseolina treatments, respectevily. The highest reduction rate $(25.0 \%)$ was detected in $P$. dactylifera $/ F$. semitictum and $F$. solani interactions in CREDO cv. Significant reduction in PRD values was detected as a result of seed treatment with the tested plant powder, attaining maximum rates in $R$. raetam / F. solani $(43.75 \%)$, F. semitictum $(33.33 \%)$, M. phaseolina
(28.57\%) and $F$. moniliforme (23.07\%), while in $P$ dactylifera treatment gave the highest reduction rates $(37.5 \%$ , 26.32\% and $25.0 \%$ ) were observed in F. solani / CREDO cv., F. solani / ANANAS cv. and M. phaseolina / ANANAS cV. Significant reductions PTD in damping-off incidence in all cantaloupe cultivars were obtained due to treatment with most of the tested plant powder, but in some treatments were non effected, however, $R$. raetam was more efficient in reducing damping-off incited by $F$. semitictum, $F$. moniliforme and $F$. solani $(42.86 \%, 28.57 \%$ and $27.27 \%$, respectively compared with control).

On the other hand, $P$. dactylifera and $C$. trifurcatum were more efficient in controlling damping-off caused by $F$. semitictum, where reduction\%, compared damping-off incidence, followed by $P$. dactylifera. This trend discussed above is similar to the observation on disease incidence by many scientists (AI-Dalmasini et. al, 2003; Ben Yephet and Nelson, 1999; Bennard and Clement, 1983; Benhamou et al, 1997; Bennard and Pesando, 1989; Boehm and Hoitink, 1992; Boehm et al., 1997; Bonsi et. al, 1995; Cariellon and Zanetti, 1979; Cotxarrera et. al, 2002; Craft and Nelson, 1996; Delaney et. al, 2001; Elad and Shteinberg, 1994; Erthart and Burian, 1997; Folman et. al, 2004; Fuchs and Larbi, 2004; Hoitink et. al, 1997; Kao and Ko, 1986; Verma and Kharmar, 2006). Also, several studies have been conducted to investigate the peculiar effects of plant extracts as fungicides, pesticides and as antibacterial agents on plant growth worldwide. The antifungal activity of Allium sativum was reported by Grewal (2006). The author, observed that essential oil of $A$. sativum on agar plate was active on Lenzites trabea, Lentinus lepideus and Polyporus versicolor. Similarly, the species antibacterial activity of ethanol extract was active on Escherichia coli, Salmonella typhosa, Shigella sonnei and Staphylococcus aureus. The author observed that water extract of the species was active on Bacillus, Klebsiella, Proteus vulgaris, S. styphosa, S. sonnei and S. aureus. Moslem and Kholie (2009) also reported the antifungal effects of neem leaf and seed extracts obtained by ethanol, on Fusarium oxysporum, Rhizoctionia solani, Alternaria solani and Sclerotinia sclerotiorum. The authors observed growth inhabitation of the tested fungi. It is important to note that bio-control agents induces the accumulation of enzymes such as Chitinnase, Peroxidase and Polyphenol oxidase which plays an important role in plant defense mechanisms against pathogens (Abd-EL-Khair and EI-Mougy, 2003). This study indicates that the application of the plant extracts increased the growth and reduced disease incidence in Casuarina equisetifolia. The increase in plant growth might be associated with secretion of auxin, gibberellins and cytokinnins and suppression of deleterious microorganism causing damping off (Gamliel and Katan, 1993). In addition to the direct antagonism and plant growth promotion, plant extracts from leaf of Azadirachta indica, seed of Azadirachta indica, bulb of Allium sativum, root of Zingiber officinale and leaf of Vernonia amygdalina increased the activities of various defense related enzymes and chemicals in response to infection by the pathogen. Many plants are endowed with defense mechanisms which can protect them against fungi (Dutta, 2003). Also, it has been reported that application of plant extracts triggers plants' latent defense mechanism in responses to infection by pathogen. Inducing a plants' own

\section{Volume 6 Issue 7, July 2017 www.ijsr.net}




\section{International Journal of Science and Research (IJSR) \\ ISSN (Online): 2319-7064}

Index Copernicus Value (2015): 78.96 | Impact Factor (2015): 6.391

defense mechanism by prior application of a biological agent is a novel strategy in plant disease management. Aqueous plant extract is rich with nutrient and microorganism. It can stimulate growth, protect plants from disease and help suppress soil borne pathogen (Quarles, 2011). In this study, it could be stated that seedlings treated with the three plants powder: stem of $R$. raetam, seed of $P$. dactylifera and mixed of leaves, stems and roots of $C$. trifurcatum increased the activities of various defense-related enzymes which led to the synthesis of defense chemical in cantaloupe cvs. The result implies that the use of three plants powder inhibited the growth and development of damping off causing fungi. Therefore, new forest protection options involving the use of bio- fungicides need to be explored in order to ensure the success of any deforestation and reforestation programs. A great interest should be focused on biofungicides that are relatively cost effective and have minimal toxicity to both mammals and the environment. Unlike inorganic fungicides, the use of organic fungicides can cause no disruption to any stable food chain.

In conclusion, many reports revealed that, plant metabolites and plant based pesticides appear to be one of the better alternatives as they are known to have minimal environmental impact and danger to consumers in contrast to synthetic pesticides (Varma and Dubey, 1999; Harborne, 1998; Gottlieb et al., 2002). Even though effective and efficient control of seed borne pathogenic fungi can be achieved by the use of synthetic fungicides, the same cannot be applied to grains for reasons of pesticide toxicity (Wodageneh and Wulp , 1997; Harris et al., 2001). Thus, there is a need to search for alternative approaches to store seeds, grains/cereals for human consumption without toxicity problems that are ecofriendly and not capital intensive.

\section{References}

[1] Abd-EI-Khair, H. and EI-Mougy, N.S. (2003). Field biological approach under organic cultivation conditions for controlling garlic black mould disease infection during storage. Egypt. J. Appl. Sci., 18(6): 50-69.

[2] Amin, A.R.; Rashid, M.M. and Meah, M.B. (2009). Efficacy of garlic tablet to control seed-borne fungal pathogens of cucumber. Journal of Agriculture \& Rural Development, 7(1): 135-138.

[3] Bahraminejad, S. (2012). In vitro and In vivo antifungal activities of Iranian plant species against Pythium aphanidermatum. Annals of Biological Research, 3(5): 2134-2143.

[4] Barrera-Necha, L.L.; Garduno-Pizana, C. and Garcia-Barrera, L.J. (2009). In vitro antifungal activity of essential oils and their compounds on mycelial growth of Fusarium oxysporum f. sp. gladioli (Massey) snyder and hansen. Plant Pathol J., 8(1): 1722.

[5] Belabid, L.; Simoussa, L. and Bayaa, B. (2010). Effect of some plant extracts on the population of Fusarium oxysporum f. sp. lentis, the causal organism of lentil wilt. Advances Environmental Biology, 4(1): 95-100

[6] Ben Yephet, Y. and Nelson, E.B. (1999). Differential suppression of damping-off caused by Pythium aphanidermatum, $P$. irregular and $P$. myriotylum in composts at different temperatures. Plant Dis., 83: 356360.

[7] Benhamou, N., Rey, P.; Chenf, M.; Hockenhull, J. and Tirilly, Y. (1997). Treatment with the mycoparasite Pythium oligandrum tiggers induction of defence-related reactions in tomato roots when challenged with Fusarium oxysporum f.sp. RadicisLycopersici Phytopathol., 87: 108-121.

[8] Bennard, P. and Clement, R. (1983). Bringing into evidence antibiotic substances from Posidonia oceanica. Rev. Int. Oceanogr. Med., 70(71): 33-37.

[9] Bennard, P. and Pesando, D. (1989). Antibacterial and antifungal activity of extracts from the rhizomes of the Mediterranean Posidonialoceanica seagrass (L) Delile. Bot. Mar., 32: 85-88.

[10] Boehm, M.J. and Hoitink, H.A.J. (1992). Sustenance of microbial activity in pottingmixes and its impact on severity of Pythium root rot of Poinsettia. Phytopathol., 82: 259-264.

[11] Boehm, M.J.; Wu, T.; Stone, A.G.; Kraakman, B.; Lannotti, D.A. and Wilson, E.G. (1997). Crosspolarized magic-angle spinning 13C nuclear magnetic resonance spectroscopic characterization of soil organic matter relative to culturable bacterial species composition and sustained biological control of Pythium root rot. AppI. Environ Microbiol., 63:162168.

[12]Bonsi, M.L.K.; Osuji, P.O.; Tuah, A.K. and Umunna, N.N. (1995). Vernonia amygdalinaas a supplement to teffstraw (Eragrostis tef). Fed to Thiopian Menz sheep. Agroforestry systems, 31(3): 229-241.

[13] Cariellon, L. and Zanetti, L. (1979). Effect of Posidonia oceqnica extracts on the growth of Staphlococcus aureus. Bot. Mar., 22: 129-131.

[14] Cotxarrera, L.; Trillas, G.M.I.; Steinberg, C. and Alabouvette, C. (2002). Use of sewage sludgecompost and Trichoderma sperellum isolates tosuppress Fusarium wilt of tomato. Soil Biologyand Biochemistry, 34(6): 46-47.

[15] Craft, C.M. and Nelson, E.B. (1996). Microbial properties of composts that suppress dampingoff and root of creeping bentgrass caused by Pythium graminicola. App. Environ. Microbio., 62: 1550-1557.

[16] Delaney, S.M.; Mavrodi, D.V.; Bonsall, R.F. and Thomashow, L.S. (2001). phzO, a gene for biosynthesis of 2-hydroxylated phenazine compounds in Pseudomonas aureofaciens 30-84. J Bacteriol., 183(1): 318-27.

[17] Dutta, A.C. (2003). Botany for degree students. Oxford University Publication ( ${ }^{6}$ th edition). 708 pp.

[18] Elad, Y. and Shteinberg, D. (1994). Effect of compost water extracts on grey mold (Botritis cinerea). Crop Prot., 13: 109-114.

[19] Erthart, E. and Burian, K. (1997). Evaluating quality and supressiveness of Austrian blowaste composts. Compost Sci. Uil, 5: 15-22.

[20] Folman, L.B.; De Klein, K.J.E.M.; Postma, I. and Van Veen, J.A. (2004). Production of antifungal compounds by Lycobaster enzymogenes isolate 3. IT8 under different conditions in relation to its efficiency as a biocontrol agent of Pythium aphanidermatum in cucumber. Bio-Control., 31: 145-154 
[21] Fuchs, J. and Larbi, M. (2004). Disease control with quality compost in pot and field trails. Paper presented at International Conference on soil and composts ecobiology. Soil ACE, Biomase Peninsular. Leon-Spain, 157-166.

[22] Gamliel, A. and Katan, J. (1993). Suppression of major and minor pathogens by fluorescent pseudomonads in solarised soil and nonsolarized soil. Phytopathology, 83: 68-75.

[23] Gottlieb, O.R.; Borin, M.R. and Brito, N.R. (2002). Integration of ethnobotany and phytochemistry: dream or reality? Phytochemistry, 60(2): 145-152.

[24] Grewal, R.C. (2006). Medicinal Plants (First Edition) Campus Books International New Delhi, India, 430pp.

[25] Harborne, J.B. (1998). Phytochemical methods: A guide to modern techniques of plant analysis. 3rd ed. Chapman \& Hall Pu., London, UK: 7-8.

[26] Harris, C.A.; Renfrew, M.J. and Woolridge, M.W. (2001). Assessing the risk of pesticide residues to consumers: recent and future developments. Food Additiv. Contam, 18(12): 1124-1129.

[27] Hoitink, H.A.J.; Stone, A.G. and Han, D.Y. (1997). Suppression of plant diseases by composts. Hort. Science., 32: 184-187.

[28] Ja Choi, G.; Soo Jang, K.; Kim, J.; Lee, S.; Cho, J.; Cho, K. and Kim, J. (2004). In vivo Antifungal Activities of 57 Plant Extracts against Six Plant Pathogenic Fungi. Plant Pathol. J., 20(3): 184-191.

[29] Kao, C.W. and Ko, W.H. (1986). The role of calcium and microorganisms in suppression of cucumber damping off caused by Pythium splendes in a Hawaiian soil. Phytopathol., 76: 221-225.

[30] Moslem, M.A and El-Kholie, E.M. (2009). Effects of neem (Azadirachta indica A. Juss) seeds and leaves extract on some plantpathogenic fungi. Pakistan Journal of Biological Sciences, 12(14): 1045-1048.

[31] Quarles, W. (2011). Compost tea for organic farming and gardening. The IPM Practitioner, 23(9): 1-8.

[32] Sahayaraj, K., Borgio, J.F. and Raju, G. (2009). Antifungal activity of three fern extracts on causative agents of groundnut early leaf spot and rust diseases. Journal of Plant Protection, 49(2): 141-144.

[33] Satish, S.; Raghavendra, M.P. and Raveesha, K.A. (2010). Management of seed-borne fungal pathogens of sorghum seeds by aqueous extract of Lawsonia inermis L. Journal Biopesticides. 3(1): 237-241.

[34] Stephan, D.; Schmitt, A.; Carvalho, S.M.; Seddon, B. and Koch, E. (2005). Evalution of biocontrol preparations and plant extracts for the control of Phytophthora infestans on potato leaves. European J. Plant Pathol., 111: 1-12.

[35] Varma, J. and Dubey, N.K. (1999). Prospectives of botanical and microbial products as pesticides of tomorrow. Curr. Sci., 76(2): 172-179.

[36] Verma, V.C. and Kharmar, R.N. (2006). Efficacy of neem leaf extract against its own fungi endophytic Curvularia lunata. J. Agric. Technol., 2: 329-335.

[37] Wodageneh, A. and Wulp, H.V.D. (1997). Obsolute pesticides in developing countries. Pestic. Information, 23(1): 33-36.

Volume 6 Issue 7, July 2017 www.ijsr.net 